\title{
Indium In 111 CHX-A DTPA Trastuzumab
}

National Cancer Institute

\section{Source}

National Cancer Institute. Indium In 111 CHX-A DTPA Trastuzumab. NCI Thesaurus.

Code C60766.

An indium In 111-labeled trastuzumab with potential use as an imaging agent. Indium In 111 CHX-A DTPA trastuzumab is chemically conjug ated via a bifunctional metal chelator molecule, 2-(p-isothiocyanatobenzyl)-cyclohexyl-diethylenetriaminepentaacetic acid (CHX-A DTPA), a backbone-substituted derivative of DTPA. This agent may allow radioimmunolocalization of HER2-positive cells. Trastuzumab, a recombinant humanized monoclonal antibody that selectively binds with high affinity to the extracellular domain of human epidermal growth factor receptor 2 (HER2), may elicit an antibody-dependent cellular cytotoxicity (ADCC) against tumor cells that overexpress HER2. 